\title{
Lampejos de um espelho em pedaços: por um cânone lírico do século XX russo
}

\author{
REMO FACCANI
}

$\mathrm{E}$ M 29 DE JUlHo DE 1956, Boris Pasternak escreveu de Moscou uma breve carta a Angelo Maria Ripellino. Embora o eslavista italiano dominasse a língua russa "tel qu'un Russe natif”, "pour des raisons de politesse ou bien quelques autres", preferia escrever-lhe "em mau francês", principalmente naquele primeiro contato epistolar.

Pasternak dizia que acabava de receber "Votre Anthologie splendide, votre présent inestimable" (a referida antologia era o volume Poesia russa do século XX, publicado por Guanda em 1954). Agradecia calorosamente ("Vous m'avez obligé pour toute ma vie") pelas páginas que lhe haviam sido dedicadas na introdução e acrescentava: "La profondeur du goût inné, montrée dans votre choix est étonnante! Vous êtes versé dans les affaires littéraires de notre mi-siècle" [lembremos que a carta é de 1956] plus qu'aucun de nous et que moi même".

Seguia-se um post-scriptum encerrado por uma frase elegante, claramente sugerida pelo nome do organizador da antologia: "Vous êtes un ange de Dieu[caracteres cirílicos] - je vous admire" (1).

É notória a eloqüência fascinante dos epistolários de Pasternak. E fica-se a perguntar como, por exemplo, Anna Akhmatova teria comentado semelhante carta. $\mathrm{O}$ que proponho aqui não quer ser medíocre exercício de retórica, mas um dos modos possíveis de procurar captar, ou ao menos vislumbrar, o conhecimento (e a consciência, a autoconsciência) que alguns dos maiores poetas russos modernos tiveram do patrimônio literário em versos de seu tempo, do trecho do século XX em que se desenvolveu sua atividade.

Em fins da primavera de 1940, Anna Akhmatova - depois de quase 20 anos de ostracismo quase total - publica uma coletânea antológica de seus versos: Iz sesti knig. Stichotvorenija (De seis livros. Poesias). No final de julho Pasternak lhe escreveu, entusiasmado. Mas acompanhemos este episódio segundo o relato deixado pela escritora Lidia Cukovskaia. Esta - que foi um pouco o Eckerman de Anna Akhmatova -, a partir do final da década de 30 foi registrando quase dia a dia os acontecimentos da vida da poetisa, seus pensamentos e lembranças; transcreveu ou decorou seus novos versos, cujos manuscritos a amiga, genial e desconfiada, queria destruir. 
"Anna Akhmatova", anota sua confidente, "procurou sob a poltrona um envelope e entregou-me". Os olhos de Lidia Cukovskaia, protegidos pelas grossas lentes dos óculos, logo reconheceram a caligrafia de Pasternak: de fato, tratava-se de uma carta dele "sobre os versos de Anna Akhmatova".

"Naturalmente, resumir uma carta de Pasternak", observa Lídia Cukovskaia, "é tão impensável quanto resumir uma de suas poesias. De qualquer forma, tentarei relatá-la em substância, reproduzir-lhe a essência".

"Parabéns pela vitória, pelo triunfo. Em Moscou há filas para comprar o livro. Nós - Sievieriânin, eu e Maiakóvski - somos seus devedores em medida muito maior do que eu até agora pensava. Uma maneira nova (que se encarna) em novos versos; o nascimento de um novo poeta ao lado de um poeta de outrora".

Seguia-se um "elenco de núcleos" e de "constelações", que remetiam a páginas do livro de Anna Akhmatova. "Com grande surpresa minha", continua Lídia Cukovskaia, "as poesias indicadas por Boris Leonidovic eram em geral tiradas de Cetki (Rosário) e de Anno Domini: tratava-se de obras "de um passado já distante, que todos, e eu assim como os outros, conhecíamos de cor". De fato, as duas coletâneas tinham saído pela primeira vez em 1914 e em 1922 (a última reimpressão remontava a 1923, mas por obra de um dos editores russo-berlinenses da emigração).

Lídia Cukovskaia expressou “a sua estupefação”. Mas Anna Akhmatova, com amável ironia, interveio para esclarecer a situação. "Vou explicar-lhe tudo agora... Ele [Pasternak] nunca tinha lido antes meus versos, asseguro-lhe. Quando comecei a publicar, ele militava no grupo Centrifuga [ou seja, na corrente mais moderada do cubo-futurismo]; sua atitude a meu respeito era, naturalmente, hostil, e ele nem sonhava em ler meus versos. Agora pela primeira vez ele os leu e - viu só? - fez uma descoberta: [caracteres cirílicos] ('A pluma roçou o teto da carruagem...'). Caro, ingênuo, adorável Boris Leonidovic!” (2)

Quis deter-me neste fragmento de crônica literária antes de mais nada para levantar o problema da autoridade de Boris Pasternak como conhecedor da obra dos poetas contemporâneos seus (autoridade que Anna Akhmatova parece pôr em dúvida) e como juiz do vasto panorama russo do século XX, que Ripellino desdobrara em sua antologia. Certa dose de parcialidade era inevitável. Pasternak, todavia, certamente estava mais a par da literatura russa do que, em seu afetuoso sarcasmo, Anna Akhmatova gostaria de nos fazer crer.

Prova disso, ainda que indireta, é o caso Maldelstam. Anna Akhmatova justificou certa imprecisão, certa hesitação mostrada por Pasternak ao tentar defender Maldelstam durante a famosa conversa (se podemos chamá-la assim) por telefone, com Stálin. Este queria um claro juízo crítico sobre o poeta que o definira, em um epigrama, "o montanhês do Kremlin", de "dedos grossos e gorduchos como vermes" e de "olhos de barata". Anna Akhmatova justificou o comportamento de Pasternak sem alegar sua ignorância ou indiferença, como poderia ter feito, pois Maldelstam era também poeta acmeísta (ou seja, do mesmo credo por ela professa- 
do). Aliás, havia tantos anos que os versos de Anna Akhmatova não eram publicados ou reeditados na URSS que seria um pouco demais pedir que a memória de Pasternak tivesse lembrança fresca e intacta daquelas poesias longínquas...

Além disso, há na carta de Pasternak um interessante esboço de sua própria genealogia poética. Igor' Sievieriânin (refugiado havia anos na Estônia, coberto de insultos pela crítica oficial soviética) recebeu de Pasternak o tributo de uma apreciação realmente corajosa. Pasternak, depois, delineou o núcleo de seu "cânone lírico virtual” (Akhmatova, Sievieriânin, Pasternak, Maiakóvski...). As conversas de Anna Akhmatova, por sua vez, propõem genealogias inéditas. Mas a este ponto terei ocasião de voltar adiante.

Até poucos anos atrás, até cerca de 1990, parece-me que não se podia dizer que o gênero antologia poética houvesse conhecido, na Rússia, a boa sorte que lhe sorrira no Ocidente. Mas no panorama da civilização russa do século XX - tanto a interna quanto a da emigração - esse gênero espalhou, um tanto desordenadamente, várias de suas bandeirolas, ora mais ora menos significativas.

Creio necessário, porém, oferecer logo algumas indicações terminológicas que ajudarão o leitor a orientar-se em tal panorama. Costuma-se fazer remontar a 1892 o nascimento oficial do decadentismo russo. Foi o ano em que Dmitri Merezkóvski pronunciou uma célebre conferência, depois publicada em 1893: Das causas do declínio e das novas correntes da literatura russa moderna, na qual proclamava que na Rússia nascia uma "arte simbólica". Naquele mesmo ano o escritor fez publicar uma coletânea de seus versos, intitulada Simvoly (Símbolos). Entre 1894 e 1895 Valéri Briussóv - talvez tomando por modelos os Poètes maudits de Verlaine publicou três coletâneas antológicas intituladas Russkie simvolisty (Os simbolistas russos).

É assim que se apresenta a situação do mundo literário russo vista do ambiente de dentro. Observando-a de fora, parece inevitável considerar o simbolismo russo como um filão - o filão mais original - do movimento decadente que se estava organizando em Moscou e em São Petersburgo (e que havia de se desenvolver com vigor por cerca de 20 anos). O fato é que não se pode definir Merezkóvski como simbolista, e menos ainda Briussóv, que tem antes fisionomia de epígono sui generis dos parnasianos.

O segundo decênio do século XX abre-se com a entrada em cena de vários movimentos pós-simbolistas (e anti-simbolistas), entre os quais sobressaem o acmeísmo e o futurismo, termos que já vislumbramos em plena juventude de Anna Akhmatova e de Pasternak (em época bastante recente firmou-se também na Rússia o termo modernizm, (modernismo), mas com uma dúvida por parte dos historiadores da literatura: entrariam nessa designação o decadentismo simbolista e as posteriores correntes vanguardistas? Ou ficaria reservada a uma literatura que a partir de certa data - final da década de 30 - esteve autoritariamente privada de qualquer 
possibilidade real de experimentalismo? É no primeiro desses significados, ou seja, na acepção mais ampla, que me referirei ao modernismo.

É verdade, por exemplo, que segundo o maior simbolista russo, talvez o maior poeta da primeira metade do século XX, Aleksandr Blok, o "final do mundo de ontem" (e, sob certos aspectos, o final de seu próprio mundo) coincidia com o ano de 1910. Por volta daquele ano ocorria uma dilaceração, uma fratura cultural irremediável. Redigindo em 1919 o prefácio ao poema Vozmedie (Nêmesis), fragmentário e inacabado (e de propósito!), escrevia Blok: "1910 significa a morte de Komissarzeskaia [a atriz Vera Komissarzeskaia], a morte de Vrublel [o pintor Mikhail Vrubel, cujo destino foi marcado pela loucura] e a morte de Tosltói. Com Komissarzeskaia desapareceu do palco a nota lírica; com Vrubel, o titânico mundo individual do artista, a tenacidade louca, a insaciabilidade de pesquisas conduzidas ao limiar da demência. Com Tolstói morreu a ternura humana, a humanidade sábia. Além disso, 1910 significa a crise do simbolismo, de que então se escrevia e falava muito, seja no campo dos simbolistas, seja no de seus adversários. Naquele ano deram a se conhecer, sem incertezas, algumas [novas] correntes literárias que se mostraram antagonistas tanto do simbolismo quanto umas das outras: o acmeísmo, o egofuturismo, e os primeiros embriões do futurismo [isto é, do cubo-futurismo]. O lema da primeira dessas correntes literárias era o homem: mas um homem de certa forma já diferente, um homem absolutamente desprovido de humanidade, uma espécie de "Adão primordial” (3).

Mas voltemos ao centro da primeira década do século, um pouco além de sua metade. Houve uma revolução - a de 1905 - que ficou sendo não somente a primeira, mas a única verdadeira revolução russa, para grande parte da intelectualidade e para muitos poetas ou futuros poetas então adolescentes, entre os quais Blok, Pasternak, e talvez para o próprio Maiakóvski. O crítico Modest Gofmam - que haveria de teorizar um movimento do "individualismo ecumênico", inspirado nas idéias do simbolista Viatchesláv Ivanov e que, mais tarde, tendo emigrado, haveria de tornar-se um sério estudioso de Púchkin - por volta de 1907 organizou uma obra intitulada Kniga o russkich poètach poslednego desjatiletija (Livro dos poetas russos da última década). Era uma antologia entremeada de perfis críticos, cujo recorte lembra um pouco Le livre des masques de Rémy de Gourmont. É um belo volume de gosto art nouveau, carregado de frisos. Lá estão reunidos (é o que se lê em uma espécie de prefácio) os "poetas russos que mais claramente expressaram a contemporaneidade, a alma contemporânea, em seu refinamento e em seu polimorfismo, em suas buscas e em suas conquistas".

O caráter programático - a seu modo - da obra não vem certamente dessas fórmulas decididamente estereotipadas, e sim da escolha dos autores. São 13 ao todo: Konstantin Balmont (1867), Valéri Briussóv (1873), Ivan Konevskoi (18771901), Andrei Belyi (1880), Zinaida Gippius (1869), Dmitri Merezkóvski (1865), Nikolai Minski (1855), Fëdor Sologub (1863), Viatchesláv Ivanov (1866), Aleksandr Blok (1880), Siérguiei Gorodecki (1884), Maksimilian Volosin (1877), Mikhail Kuzmin (1875). São 13, assim como (poderia observar-se um tanto maldosamente) 
os comensais evangélicos da Última Ceia. Mas entre eles é difícil encontrar quem represente Cristo: quando muito poderemos vislumbrar um anticristo, o luciferino Briussóv. De qualquer forma, o organizador da antologia seguramente não se sentia bafejado pelos ventos do final, da catástrofe, como se sentiram depois Blok e outros simbolistas.

Os poetas selecionados por Gofmam tinham idades muito diferentes: iam de Minski, com mais de 50 anos, a Gorodecki, com pouco mais de 20, cuja primeira coletânea (que acabava de sair, talvez, ou estava ainda no prelo) havia agradado a Briussóv, Volosin e Blok. Contudo, segundo o organizador, eram eles os principais representantes da "nova explosão romântica" que trouxera à luz os simbolistas e os decadentes. Ficavam fora da antologia as duas figuras mais prestigiosas dentre os anunciadores, os precursores do modernismo: Vladimir Soloviov e Innokenti Anienski. É verdade que Soloviov era mais conhecido como filósofo idealista e teólogo do que como finíssimo poeta e elaborador do que seria a poética simbolista; nascera em 1853 e morrera em 1900; mas um dos poetas da antologia, Konevskoi, havia morrido em 1901... Quanto a Anienski, que morreria em 1909, depois de ter publicado somente uma coletânea de versos em 1904, Tichie pesni (Canções em voz baixa), quase escapara à atenção dos críticos. Além do mais, usava o pseudônimo de Nik. T-o, que podia ser lido como Nikto, ou seja, Ninguém. Diretor de ginásio, Anienski era grande conhecedor da literatura clássica e alcançou maior atenção com sua coletânea posterior, póstuma: Kiparisovyj larec ( $O$ cofrinho de cipreste).

Mas também ficou fora da antologia, por exemplo, Nikolai Gumilóv (nascido em 1866), alguém de 20 anos que, entretanto, já se havia revelado em 1905, com a coletânea Put' konkvistadorov (O caminho dos conquistadores). Provavelmente já entregara ao prelo outro livro de versos: Romanticeske cvety (Flores românticas, 1908) e, com Gorodecki, foi um dos fundadores do acmeísmo.

Gumilóv, de 1910 a 1918, foi marido (o primeiro dos maridos) de Anna Akhmatova.

Em 30 de junho de 1940, Lídia Cukovskaia, a confidente da poetisa, fez esta anotação: "Hoje conheci Anienski. Devo isso a Anna Andréievna". Durante um dos encontros habituais, Anna Akhmatova "pôs-se a falar de Anienski. Já por mais de uma vez - escreve a confidente - ela o recordou como poeta extraordinário. Fui obrigada a reconhecer minha ignorância total”. Foi então que Anna Akhmatova resolveu remexer livros e várias preciosidades de sua biblioteca amontoadas atrás da cômoda que lhe servia também de escrivaninha; afinal, descobriu o volume de Anienski. "Anna Andréievna sentou-se no divã e pôs os óculos. - Aqui está, agora você verá que poeta ele era... Como era imenso. É surpreendente que você não o conheça, porque todos os poetas [de minha geração] descendem dele: Óssip [Maldelstam], Pasternak, eu, e até mesmo Maiakóvski. Leu-me quatro poesias, de fato excepcionais... Percebe-se realmente, muito nítido, o som dela mesma [Anna Akhmatova] e percebe-se também o som de Pasternak" (4). 
Vemos, portanto, transparecer, nas palavras de Anna Akhmatova, outro núcleo de cânone lírico virtual, com Anienski fazendo as vezes de progenitor.

Nas antologias do século XX russo Anienski encontra, naturalmente, acolhida, mas acolhida sóbria. Entretanto, a primogenitura é em geral concedida a Solovióv. É o que acontece na obra de Ripellino; é o que acontece também na coletânea que em alguns aspectos serviu de modelo a Ripellino, ou seja, a Antologija russkoj liriki pervoj cetverti XX veka (Antologia da lírica russa do primeiro quartel século XX), preparada por I.S. Ezov e E.I. Samurin, publicada em Moscou em 1925 e republicada há alguns anos em edição fac-similar.

Essa é uma antologia realmente histórica. Suas quase 700 páginas acolhem 128 poetas (dos quais "já nenhum está entre os vivos", como nos informa o editor que lançou a obra: a última a partir, no outono de 1990, foi Irinina Odoevceva, viúva do acmeísta Georgi Ivanov, e emigrée que voltara à pátria em 1987; na linha dessa melancólica contabilidade poderíamos acrescentar que mais de um desses poetas, na plenitude da maturidade artística - bastaria lembrar Maldelstam, Nikolai Kiliuóv, Siérguiei Klyckov, Vladimir Narbut, Pëtr Oresin, Siérguiei Teretiakov - foi vítima das repressões stalinistas e que, mesmo 10, 15 ou 20 anos depois, nenhuma antologia iria sonhar em lhes abrir as páginas).

Mas a antologia de Ezov e Samurin aparecera em um período mágico da história da cultura soviética. Pouco antes surgira o movimento construtivista. Estava para nascer o grupo do Oberiu (5), cuja parábola encerraria, no final da década de 20 , a grande estação do modernismo russo.

A antologia de Ezov e Samurin é uma espécie de monumento àquele período e àquele clima; não surpreende que por muitas gerações de leitores russos - na década de 30 e especialmente após a Segunda Guerra Mundial - essa obra fosse destinada a se tornar um verdadeiro livro sagrado: sagrado e proibido, procuradíssimo, mas fechado nos famigerados Specchràn (depósitos especiais das bibliotecas soviéticas, aos quais só tinham acesso alguns pesquisadores e consulentes privilegiados). Era uma obra na qual, nas diversas secções organizadas, triunfavam a variedade e o pluralismo: poetas não-vinculados a um grupo em particular; precursores da poesia revolucionária; poetas camponeses; poetas proletários.

Lá encontramos Nikolai Gumilóv, preso em 3 de agosto de 1921 por atividade contra-revolucionária (acusação que hoje se mostra mais frágil do que nunca) e, três semanas depois, fuzilado. Encontramos um numeroso grupo de poetas émigrés - que nos anos do comunismo de guerra haviam abandonado a República dos Sovietes. de Merezkóvski a Zinaida Gippius, Balmont, Georgi Ivanov, Siervieriânin, Ivan Bunin, Vladislav Chodasevic, Marina Tzvietáieva... A distribuição decerto é às vezes discutível: os organizadores incluem, por exemplo, no grupo dos poetas camponeses, Siérguiei Iessiênin, o maior representante do imagismo, de modo que a $\mathrm{Hos}^{-}$ pedaria dos viajantes da beleza (este era o nome de uma série de almanaques imagistas) - aloja somente três poetas. 
A exclusão mais impressionante é a que diz respeito aos próceres do futurismo alógico, transmental, da assim chamada zàum': Aleksei Krucënych, Iliá Zdaniévich, Aleksandr Tufanov etc. É o sintoma de uma recusa do experimentalismo extremo, a delimitação inicial de um território dentro do qual a arte deve se desenvolver. Um sinal, apenas: não é ainda o arame farpado, e por esse arame farpado ainda não passa a corrente elétrica.

A década de 30, no que diz respeito a antologias, pode ser considerada beloe pjatnò (mancha branca, como diriam os russos): pouco menos que um deserto. $\mathrm{O}$ suicídio de Maiakóvski encerrou a estação - a primeira estação - dos poetas dilapidados (segundo a fórmula vibrante e apaixonada de Roman Jakobson). "Existem duas frases célebres sobre esse período", escreveu Pasternak em um esboço autobiográfico de seus últimos anos. "Que a vida se tornara melhor, mais alegre, e que Maiakóvski era e continuava a ser o maior e o mais dotado dos poetas da época". As frases foram pronunciadas em 1935 por Stálin. "Pela segunda dessas frases", continua Pasternak, "agradeci em carta ao autor de tais palavras, pois me livravam do exagero de significação que começaram a atribuir-me... no tempo do Congresso dos Escritores" (no primeiro congresso dos escritores soviéticos, em agosto de 1934, Nikolai Bukharin havia lido uma comunicação em que definia Pasternak como o maior poeta russo vivo). Quanto a Maiakóvski, são ainda palavras de Pasternak, "começaram a impô-lo à força, como as batatas no tempo de Catarina [II]. Foi sua segunda morte. Desta ele não tem culpa".

No tempo em que escreveu essas linhas - em 1956 - Pasternak podia afirmar: "Amo minha vida e estou contente com ela. Não preciso de que a enfeitem com dourados suplementares. Uma vida sem segredo e sem reserva, uma vida entre espelhos brilhantes de um mostruário é para mim inconcebível". Mas sua produção, sobretudo durante a segunda metade da década de 30 , ia tornando-se cada vez mais incerta, vulnerável, trabalhosa, embora ele conseguisse escapar à condição de verdadeiro emigrado dentro de seu país, como aconteceu, por exemplo, com Anna Akhmatova e, especialmente, com Maldelstam.

A partir da década de 40 (desde 1947), começa a voga das grandes (em sentido físico, em número de páginas) antologias jubilares - publicadas por ocasião do trigésimo ou quadragésimo aniversário da Revolução de Outubro e de outras efemérides. São antologias mais ou menos do regime, organizadas por personagens desconhecidos ou semidesconhecidos (Aleksandr Blok, que saudara a Revolução de Outubro com notório entusiasmo, ao comemorar Púchkin, em 1921, já advertia contra os cinovniki, os "funcionários", prontos a dirigir os rumos da poesia, a atentar contra sua "arcana liberdade"). São antologias compiladas segundo critérios que traem a persistência de determinadas idées fixes como também uma gradual evolução (nem sempre para melhor) das concepções relativas à "produção poética que merece passar às antologias, e, portanto, entrar no cânone" (e quase sempre se trata de produção na qual, ao redor de nomes de poetas verdadeiros, autênticos, 
espumeja um ilimitado oceano de mediocridade). Também podiam ocorrer compromissos ou concessões por parte de autores célebres, diante de uma forma de extorsão mais ou menos explícita: por exemplo, em 1954, Anna Akhmatova deixou-se induzir a oferecer, ao compilador de plantão, versos que celebravam o poder soviético e que a poetisa depois repudiou; ela assim agiu somente para tentar favorecer a libertação de seu filho (nascido do casamento com Gumilóv) que pelo simples fato de ter o sobrenome de um inimigo do povo vinha sofrendo, desde meados da década de 30, prisões e condenações, e em 1954 se achava relegado a alguma geleira do Gulag.

Interessante, sob este aspecto, e de certa forma paradigmático, é o ano de 1977. Foi celebrado com duas enormes antologias: 60 let sovetskoj poèzii ( 60 anos de poesia soviética), em quatro volumes, e Sovetskaja poèzija (Poesia soviética), em dois volumes, seguidos de um terceiro, Russakaja poèzija nacala XX veka / dookjabr'skij period / (Poesia russa de inícios do século XX / periodo pré-revolucionário /). Exceto este último, encadernado em amarelo, todos os demais estão, naturalmente, encadernados em vermelho.

Tanto o primeiro volume - 60 anos de poesia soviética - quanto o dedicado à poesia russa anterior à revolução se abrem com o nome de Máximo Gorki -, sim, com o nome do autor de Na dne (O submundo) e de $M a t^{\prime}$ ( $A$ mãe) -, que havia deixado algumas obras em verso. Para os organizadores das antologias, o cavalo de batalha de Gorki é uma famosa Pesna o burevestnike (Canção da procelária), escrita em 1901 e destinada a passar incessantemente de uma crestomatia a outra. O que ela tem de curioso é o fato de ser escrita em versos (em octossílabos fáceis, ou tetrâmetros trocaicos, como seria mais exato dizer), sem rima e impressos sem interrupção na página, de modo a dissimular, à primeira vista, seu caráter métrico.

O volume da lírica russa de antes da Revolução apresenta, portanto, um grupo de poetas que, em 1925, Ezov e Samurin haviam educadamente confinado à seção dos precursores da poesia pré-revolucionária. Em seguida começam a despontar os nomes dos grandes modernistas - de Briussóv a Belyi, a Anienski (que está bem representado), a Anna Akhmatova, a Maldelstam, a Pasternak, a Marina Tzvietáieva... Entre eles despontavam muitos outros nomes, de personagens francamente marginais, hoje esquecidos, que talvez ofereçam ao leitor uma ou duas líricas e desapareçam, sem the deixar sombra de saudade.

Aparecem alguns emigrados, entre os quais Balmont, Viatchesláv Ivanov, Sievieriânin. A escolha, de qualquer forma, é decididamente imprecisa, repassada de vazios e de ausências. Fica ignorado (e é muito estranho) um poeta como Blok, assim expulso do início do século XX, por motivos sobre os quais seria inútil quebrar a cabeça em busca de um simulacro de justificação (tanto mais que a introdução o cita repetidamente por certas afirmações suas, em polêmica com os acmeístas...).

Nos dois volumes de Poesia soviética e nos quatro de 60 anos de poesia soviética forma-se um grande caldeirão, que aproxima e mistura uma pletora de poetas 
russos de todos os níveis e de poetas soviéticos de outras nacionalidades (traduzidos em russo, não se sabe com quanta exatidão e liberdade). Em ambas as antologias é acolhido somente um grande poeta de nacionalidade diferente, que escreve em russo: Olzas Suleimenov, do Casaquistão. Mas não há lugar, por exemplo, para Fazil Iskander, da Abcásia, poeta e prosador de mérito, que também escreve em russo e nunca foi muito bem visto pelo establishment literário soviético. E nem se fale em Guenadi Aigui. Este poeta russo neotransmental ou neodadaista era originário de Tchuvache, de onde lhe veio a língua materna e foi estimado por Pasternak e por Mikhail Svetlov...

Tudo isso hoje me faz parecer ainda mais ingênuo e simplista um sonho de juventude que comecei a acalentar há uns 30 anos, durante minha primeira estada na União Soviética. Entre outras coisas, eu estava decidido a coletar material para uma antologia de poetas soviéticos que, embora não fossem russos de nacionalidade, usassem a língua russa em suas obras (havia, afinal, um prosador bilíngüe, como Cingiz Aimatov, nascido em Kirghiz; havia os épicos prosadores bilíngües da Geórgia; havia uma poetisa jovem, mas já bem conhecida, como Bella Achmadulina, em cujas veias corria sangue tártaro e italiano; havia, principalmente, Suleimenov e Iskander). Eu alimentava a idéia de que no dia em que o império soviético se dissolvesse como Estado (nem se podia supor que não viesse a se dissolver: isso estava na ordem dos movimentos históricos), nesse dia a língua russa teria uma sorte mais ou menos semelhante à do latim: dos espaços ilimitados da finada República dos Sovietes surgiriam um novo Marcial, um novo Sêneca, talvez um Santo Agostinho, um São Jerônimo, um Ausônio e assim por diante (hoje, no Cáucaso, na Ásia Central, no Báltico, as escolas ensinam russo - quando ensinam - como segunda ou terceira língua...).

Mas voltemos às nossas antologias de regime. E procuremos descobrir seu mecanismo gerador, por assim dizer. Os cinovniki, os burocratas da literatura que compilavam tais antologias, pareciam atentos a alguns princípios interrogáveis. A poesia, mesmo quando não fosse comemorativa, não poderia deixar transpirar a menor desconfiança, a mais leve sombra de malquerença para com o regime e a ideocracia que o sustentava. Devia, quando menos, manifestar patriotismo, ou no mínimo, exaltar o homem russo, a natureza russa, a paisagem russa. Devia ser compreensivel.

Existe a transcrição taquigráfica de um debate que se seguiu a uma leitura de versos feita por Maiakóvski, poucas semanas antes do suicídio. Alguém do público - um membro do Komsomòl, ou um jovem operário, ou talvez um e outro censurou com dureza a "incompreensibilidade" da poesia de Maiakóvski (ou melhor, de sua linguagem poética) e predisse-lhe que ele seria rapidamente esquecido no límpido e luminoso futuro da arte soviética. Maiakóvski respondeu: "Volte daqui a cem anos e então falaremos disso" (6).

Pasternak, por sua vez, viveu dificuldades próximas desse mesmo problema, que o levaram, na década de 30 , a se afastar sempre mais dos escritos de juventude 
(escritos que acabou quase por repudiar) e a caminhar para uma verbalização simples e, ao mesmo tempo, densa (mas eu diria que isto representa o caminho e o resultado de uma busca de expressão que permanece, enfim, fortemente pessoal). Pasternak chegou a retocar e por vezes a reescrever grande parte das obras do período futurista e pós-futurista. Uma tese sustentada até mesmo pela crítica russa (e da qual há indícios no comentário às novas reedições das obras de Pasternak) não deixa de ser curiosa: é que, embora fascinado pelos versos do primeiro Pasternak, Ripellino - por uma bizarra ironia da sorte - teria involuntariamente contribuído para persuadir o poeta da necessidade de revisão de algumas de suas líricas, em particular do texto epônimo de Sestra moja - zizn' (Minha irmã vida). Numa carta do poeta escrita a Ripellino em agosto de 1956 - que estava preparando uma antologia de Pasternak - aparece um post-scriptum no qual se esclarece o significado de certas palavras e imagens de algumas obras, em geral da juventude ou da primeira maturidade. Pasternak respondia, evidentemente, a um pedido de explicações de Ripellino, sabendo-o perfeito conhecedor do russo e da poesia russa do século XX. É mais que provável que Pasternak visse no episódio uma confirmação de que era justo e natural seu anseio de simplicidade, de simplicidade elaborada (este caso também acrescenta uma pedrinha de tons fantasiosos ao mosaico de outros casos um tanto lendários da vida de Ripellino...). O fato é que em 1957 sai aquela antologia de Pasternak. E remontam a 1957 tanto a chamada Vërstka, ou seja, a primeira prova de Sichotovorenija $i$ poèmy (Líricas e poemas) quanto a segunda prova dessa obra de Pasternak. O livro nunca foi lançado, em razão do escândalo provocado pela publicação de Doutor Jivago. Mas as provas se conservaram e, no tocante ao texto epônimo de Minha irmã vida, trazem correções que amadureceram, podemos supor, entre 1956 e 1957, correções que o poeta pedia que fossem incluídas sine qua non, ou seja modificações das quais dependia a inclusão ou não da poesia no volume. Assim, os desejos de Pasternak foram essencialmente respeitados, embora post mortem, na edição de suas poesias publicada em 1965, com belo prefácio de Andrei Siniavski, que alguns meses depois foi preso (ou melhor, quem foi preso foi seu alter ego Abram Terc, mas, naturalmente, foi Siniavski quem cumpriu a pena).

Muitos anos antes, Anna Akhmatova não havia poupado duras críticas à coletânea de Pasternak Vtoiroe rozdenie (Segundo nascimento), publicada em 1932, coletânea que rotulava com desprezo de "tentativa de ser compreensível" [popytka byt' ponjatnym]. Dado que Anna Akhmatova encarna da melhor forma possível a voz da resistência da "arcana liberdade" da poesia (como a haviam concebido Púchkin e Blok), vale a pena recordar algumas de suas atitudes e reações. Em 1940, quando estava para sair sua coletânea de versos De seis livros, a que me referi de início, já estava também no prelo outra coletânea sua, de caráter antológico e muito mais volumosa. Um dia (sabemos, mais uma vez, graças a Lídia Cukovskaia), a poetisa recebeu a visita do diretor da companhia editora, que the mostrou um prefácio cheio de elogios. "Eu lhe disse", contou Anna Akhmatova à sua confidente, "que é constrangedor, em minha opinião, ver tantos elogios a mim mesma impressos em meu próprio livro. Mas ele me respondeu: 'E ainda vai haver muitos ou- 
tros!..”". A conversa passou depois ao pedido da editora de que se eliminassem duas poesias. “...Eu”, contou Anna Akhmatova, "não me pus a insistir e a discutir, [tanto que] ele ficou até admirado da facilidade com que consenti em retirá-las e substituí-las". O diretor perguntou-lhe, porém, qual o significado de dois versos de uma das poesias eliminadas (poesia escrita em 1922: "My ni edinogo udara / $\mathrm{Ne}$ otkonili ot sebja" ("Nem sequer a um golpe / nós nos quisemos subtrair"). A resposta foi que "um poeta não pode explicar suas palavras a dezenas de milhares de leitores. Se algo permanece incompreensível, é melhor não publicá-lo" (7).

Os burocratas da literatura, quando se transformavam em organizadores de antologias de poetas, demonstravam (como foi afirmado por mais de um crítico) sensibilidade estética de "nível ginasial". Suponho que suas escolhas também fossem influenciadas pelo apego enraizado a certos aspectos técnico-formais do discurso poético russo. Acredito que nunca publicariam Nasedsij podkovu (Aquele que encontrou uma ferradura), longo e inquietante fragmento pindárico de Óssip Maldelstam, como não publicariam certos trechos das poesias de Pasternak, nas quais afloram concessões mais ou menos abertas ao verso livre. Nem é bom falar, além disso, na poesia que encerra, que lacra Minha irmã vida, sobre cuja estrutura métrica talvez exista meia dúzia de opiniões discordantes. Isto por que a civilização poética, ou melhor, a civilização do verso, a stichovaja kul'tura russa (como a definia Juri Tynianov), contando somente com dois séculos e meio de vida, fez com que a poesia russa chegasse praticamente até nossos dias dentro do sulco de uma tradição que não conheceu as grandes fraturas do Ocidente e que continuou a confiar muito de sua simplicidade formal aos versos binários e ternários clássicos da versificação silábico-acentuada (ou silabotônica, como a chamam os russos), às estruturas estróficas mais ou menos fechadas, à rima etc. Por isso é que o verso livre foi rejeitado - oficialmente, pode-se dizer - ou relegado à margem do trabalho, do ofício literário. De início, no começo da era soviética, por julgar o verso livre imitação inoportuna e tola de fenômeno da Europa ocidental e burguesa; em seguida, a partir do degelo de Kruschev, por julgá-lo território experimental destinado a continuar periférico e a ter futuro incerto e nebuloso. De tudo isso os organizadores de antologia souberam tirar as devidas conseqüências.

É óbvio que, tendo sob os olhos as poesias de Pasternak em redações juvenis e em outras mais tardias, os organizadores não hesitaram em escolher estas últimas. Valha como exemplo de todas uma estrofe de Minha irmã vida, cuja reescritura teria sido influenciada pela carta de Ripellino: [caracteres cirílicos] (1922) “...Cto tól'ko narvëtsja, razlájavsis', tormóz, / na mírnych sel'can v zacholiustnom viné, / S matrácev gljadját, ne mojá li platfórma, / I sólnce, sadjás', soboléznuet mné"; [caracteres cirílicos] (1957) “...Cto tol’ko zakát ozarit chtorjánok, / Tolpóju tesnjáscichsja na polotné, / Ja slýsu, cto éto ne tot polustánok, / I sólnce..." (em tradução livre e explicativa: “...quando o [barulho do] freio [da locomotiva, dos vagões], pondo-se a latir cada vez mais forte, esbarra / em pacíficos camponeses imersos em perdida e remota luz cor de vinho, / dos assentos, dos forros [do vagão do trem, os companheiros de viagem] olham para ver se não é minha plataforma [a plataforma da 
minha estação] / e o sol, caindo [no horizonte], me dá seus pêsames”; “...quando o pôr-do-sol ilumina, envolve em sua luz as camponesas / que se espremem como a multidão na calçada, / eu ouço [dizer] que a estaçãozinha não é aquela [que aquela estaçãozinha não é a minha] / e o sol...”).

Um caso particular é o da mais bela lírica de amor de Maiakóvski e talvez de todo o século XX russo: Pis'mo Tat'jane Jakovlevoj (Carta a Tatiana Jakovleva). A destinatária era uma emigrada russa, muito jovem, de quem o poeta se enamorou durante a permanência em Paris, em 1928. Parece mesmo que quis casar-se com ela e convencê-la a voltar à Rússia, de onde ela emigrara para a França alguns anos antes. Cito os últimos versos: [caracteres cirílicos] "sjudá, / idi na perekrëstok // moich bol'sich $i$ neukljuizich ruk..." ("Vem cá, / vem à encruzilhada // de meus grandes / braços desajeitados. // Não queres? Fica onde estás, aproveita o inverno; / / afinal / até esse desacato / engoliremos. / / Pois mais cedo ou mais tarde / hei de te agarrar / - fica sabendo - // sozinha, ou com Paris também").

Pois bem, essa poesia, escrita em 1928, ficou inédita até abril de 1956, $26^{\circ}$ aniversário da morte do autor (quando foi publicada em Nóvi mir, dirigida por Konstantin Simonov, que se mantinha fiel à linha liberal inaugurada por Aleksandr Tvardovski). Ficou inédita esse tempo incrivelmente longo por uma confluência de motivos: de um lado, a inegável recusa de ver a imagem de Maiakóvski manchada pelo amor a uma emigrada (que acabou casando com um francês e depois se mudou para os Estados Unidos); por outro lado, houve talvez ciúme de Lili Brik, que queria aparecer a todo o custo como a única verdadeira musa do autor da Nuvem de calções. Seja como for, essa autêntica jóia do talento lírico de Maiakóvski nunca teria como entrar em um sóbrio cânone lírico do século XX, publicado, digamos, no Ocidente, como, por exemplo, o proposto na antologia Priglusënnye golosa: poèzija za zeleznym rubezom (8).

Em matéria de antologias (e de cânones) oficiais, creio que valha a pena dar uma olhada ao cânone lírico do século XX pré-revolucionário, que a "crestomatia" Russkaja literatura XX veka (Literatura russa do século XX) ofereceu a muitos estudantes das faculdades de filologia - isto é, das faculdades de letras - da União Soviética. Essa antologia esteve em uso por um quarto de século: apareceu na década de 1960 e teve sua reimpressão mais recente (suponho que a última) em 1987. Seu autor é N.A. Trifonov (nada que ver, obviamente, com o célebre prosador!).

A parte do manual reservada à poesia divide-se em duas seções contrapostas. A seção intitulada "Literatura modernista-decadente" está dividida, com razão, nas sub-seções habituais: "simbolistas", "acmeístas", "futuristas". Contudo, um Maldelshtam, por exemplo, é incluído no campo simbolista, em que sobressai, entre outros, Andrei Biéli, mas não alguém como Aleksandr Blok. Mikhail Kuzmin, figura notoriamente inquieta, é acolhido tanto entre os simbolistas quanto em 
território acmeísta. E entre os futuristas, nada de encontrar Maiakóvski. Mas, calma! A segunda seção intitula-se "Rumo à superação do decadentismo", e é então que o manual concede 20 páginas a Briussóv (decadente em rumo de se superar...); pouco menos de 30 a Blok e seis a Iessênin. Maiakóvski está presente, mas só em algumas páginas menores de prosa. Entretanto, sabemos que ele era ministrado em doses cavalares nas escolas de todas as ordens e graus. Na universidade, em particular, era lido em vastas compilações inteiramente dedicadas aos seus versos. Mas esta reticência quanto ao Maiakóvski pré-revolucionário explica-se, quase certamente, pelo receio de arranhar, aos olhos dos estudantes, sua imagem monolítica de "o maior poeta da era soviética".

O grande excluído desta crestomatia, que consegui consultar na edição de 1966, não podia ser senão Pasternak. É verdade que em 1965 fora publicada uma obra sua, apresentada por Siniavski na prestigiosa Biblioteka poèta. Curiosamente, esta obra tinha a mesma tiragem da crestomatia: 40 mil exemplares. Contudo, não era absolutamente o caso de aproximar mentalidades jovens com alguém que, durante anos, enquanto vivia e depois de morto, havia sido alvo de carradas de lama.

Entre as antologias soviéticas não creio que se deva omitir, afinal, as destinadas ao público estrangeiro, e em particular a estudantes estrangeiros. Foram organizadas, portanto, com fins pedagógicos, mas, apesar disso, isentas do conformismo servil e da parcialidade grotesca dos manuais para circulação interna. Aqui me limitarei a Stranicy sovetskoj poèzii (Páginas de poesia soviética), antologia com notas de comentário em inglês, organizada por Ju. Chalfin e publicada em 1984, em Moscou. A seleção encerra cerca de 20 nomes, que vão de Blok a Ievtuchenko. É, pois, uma seleção que deixa encapsulado e sovietizado o maior representante do simbolismo russo (nascido, lembre-se, em 1880 e falecido em 1921). E o sovietiza de modo hiperbólico, pois não só lhe concede muito mais espaço que a outros poetas, mas acolhe também poesias de sua juventude, escritas no final do século XIX.

A Blok segue-se Maiakóvski. E convém retomar uma afirmação de Lili Brik, para quem uma das obsessões de Maiakóvski era a de chegar a substituir Blok no imaginário cultural russo. O organizador desta antologia reservou-lhe, ao menos, um segundo lugar. Mas ignorou inteiramente Maldelstam. Além disso, talvez para dar à sua seleção um toque de originalidade, acolheu cinco poesias de Vozniessiênski e nada menos de 15 de Arseni Tarkovski (pai do diretor de cinema). Encontramos também uma dúzia de líricas do poeta judeu David Samoilov (nascido em 1920 e desconhecido, ou quase, do leitor italiano), ou seja, de um poeta que sempre se distinguiu pelo refinamento e pelo espírito de independência (consta, por exemplo, que na época soviética ele nunca participava das sessões da União dos Escritores...). Esta antologia reproduz, entre outras coisas, uma poesia intitulada Smert' poèta (Morte de um poeta), o mesmo título de uma poesia de Pasternak em memória de Maiakóvski e, sobretudo, de outra poesia que Mikhail Lermontov escreveu em 1837 em memória de Púchkin (e que, como se sabe, custou a seu autor a transferência de São Petersburgo para um distrito militar do Cáucaso, da "Sibéria quente", segundo uma designação do século passado...). 
O epicédio de Samoilov foi composto em honra de Anna Akhmatova, e está carregado de uma ternura e de uma força que, em 1966 - ano em que a poetiza faleceu - não deviam ser particularmente bem vistas pelo ambiente literário oficial da União Soviética. Mas na antologia de Chalfin (que na verdade não é dedicada à poesia soviética, mas à poesia russa do século XIX, ainda que com muitas lacunas e com critérios de seleção que beiram à extravagância) é interessante o relevo excepcional concedido a Blok, que é colocado, dentro da poesia russa de nosso século, em posição análoga, pode-se dizer, à ocupada por Púchkin na poesia russa do século anterior.

O trabalho de organização de antologias da lírica russa do século XX torna-se maciço e sistemático a partir de 1990. Antes desta data, começando pelos poetas contemporâneos, grosso modo, de Iosif Brodki, a difusão de muito da poesia subterrânea havia encontrado canais graças ao samizdàt [isto é, à "auto-editoração", palavra derivada de sam (por si) + izdat, abreviatura de $i z d a t e l$ 'stvo ("casa editora")] e, ainda, graças ao tamizdàt, ao fato de se publicar "lá" [tam], ou seja, no Ocidente. Pois no Ocidente, a partir de 1980, uma enorme quantidade de material, bastante heterogêneo e tendencioso também, foi publicada sob a direção dos émigrés Konstantin Kuzminski e Grigori Kovalov, que organizaram os cinco tomos (e nove volumes) da Antologia da poesia russa contemporânea / A lagoa azul (Antologija novejsej russkoj poèzii u Goluboj laguny / The Blue Lagoon: Anthology of Modern Russian Poetry).

A Rússia destes últimos anos tem conhecido diversas compilações, por vezes bastante elitistas, da poesia mais recente - da produção lírica ligada a alguns grupos da neovanguarda, entre os quais parece distinguir-se, pelo empenho e pela qualidade, a chamada escola meta-realista, em que ressoam certas predileções e certos resultados da Language School norte-americana. Um de seus teorizadores apaixonados é um ensaísta de valor, Mikhail Epstein, alguém que, vejam a coincidência, hoje mora e trabalha nos Estados Unidos... Mas estamos, aqui, em terreno essencialmente experimental, magmático, e as coletâneas de textos que o exploram são em geral tentativas inevitavelmente provisórias - e, muitas vezes, incertas - de pôr em dia o fluido panorama de um work in progress.

Mas o campo realmente sugestivo, fascinante, percorrido pelos organizadores mais sensíveis e preparados é o do modernismo, ou melhor, do "século de prata", como se prefere chamá-lo. Esta denominação deve-se - parece - ao filósofo Nikolai Berdiaev, que a teria criado ao pensar no "século de ouro", na extraordinária floração da poesia russa do século XIX, durante o breve período em que a cena literária, sobretudo em São Petersburgo, esteve dominada pela personalidade e pelo gênio de Púchkin. Para Berdiaev, e não só para ele, o fim do século XIX e os inícios do XX representaram, no campo da poesia (e no da filosofia), um autêntico renascimento da cultura russa. 
Seria quase impossível oferecer até um mero elenco das antologias que nos últimos seis anos foram dedicadas à poesia e aos poetas do "século de prata". Entre elas figuram seleções que têm como tema os gêneros ou os filões (por exemplo, "o soneto no século de prata”, "o século de prata em São Petersburgo", "os poetas da revista Satirikon", esboços, mais ou menos tímidos de uma "poesia amorosa do século de prata" etc.). Poderíamos até lembrar algumas antologias, como Kovceg (O escrínio): "poesia da primeira emigração"; e o primeiro volume da "literatura russa de além-fronteiras". Paralelamente, foi publicada uma extensa coletânea de manifestos literários e declarações programáticas referentes ao período modernista (Poeticwskie tecenija v russkoj literature konca XIX - nacala XX veka (Correntes poéticas da literatura russa entre o final do século XIX e o início do século XX); e foi traduzido em russo o volume "Do decadentismo à vanguarda", da História da literatura russa, organizada por Efim Etkin, Georges Nivat, Ilià Serman e Vittorio Strada.

Entre as novas antologias do "século de prata" sobressai a dedicada, em 1993, ao período de 1890-1917, a qual poderia servir de modelo a futuras antologias de períodos posteriores da poesia russa. É uma antologia que representa, creio, a tentativa mais original de alcançar (de modo polifônico, pode-se dizer) a determinação e a elaboração de um cânone lírico. De fato, essa antologia se deve ao trabalho de um grupo de escritores e críticos literários (cerca de 15), cada qual responsável pela antologia de certo número de poetas. E Solovióv recebe (definitivamente?) a consagração, como progenitor do modernismo russo...

Estamos, pois, assistindo a uma recomposição do espelho - ou do mosaico, se quisermos - do cânone lírico do século XX russo. Mas na Rússia esta recomposição fica, por ora, voltada para o "século de prata". Não creio, porém, que se deva interpretá-la somente como fenômeno de investigação e recuperação de um passado subtraído ou latente, escondido no palimpsesto da história russa; muito menos como contemplação encantada e nostálgica do passado. O que penso é que a relação entre esse passado e o presente, incerto e tumultuado, é muito mais complexa (e não é este o lugar de sondá-la e perscrutá-la como mereceria). Tenho para mim que aos olhos de grande parte dos leitores russos, talvez da maioria (em especial dos representantes da nova intelectualidade), esse passado é, entre outras coisas, uma espécie de fértil húmus cultural. É o húmus no qual cresceu a arte do maior poeta da segunda metade de nosso século: Iosif Brodsky, que em tantos aspectos soube recapitular genialmente e tornar suas as conquistas - reais e potenciais - do que houve de mais alto e inovador no século XX russo. É o húmus que pode assegurar à indispensável, misteriosa, "arcana liberdade" da poesia - segundo a fórmula de Blok que anteriormente recordei - a possibilidade de recomeçar a viver e a se desenvolver em sua febril e atormentada plenitude.

Notas

1 B. Pasternak, Pis'ma k A. Ripellino, "Russi/Rossija", 4, 1980. 
2 Lídia Cukovskaia, Zapiski ob Anne Achamtove, kn. I, 1938-1941, Moskva, 1989, p.137-138.

3 Cfr. A. Blok, La Nemesi, Turim, 1980.

4 Lídia Cukovskaia, op. cit., p. 123).

5 Obiedinieni Realnovo Iskusstva - Associação da Arte Real (nota do tradutor).

6 Cf. também os versos de Maiakóvski: "Quisera que minha terra me entendesse; // se não me entenderem, / bem, paciência: // por minha terra / passarei de rastros, / / como passa uma chuva oblíqua, enviesada".

7 Lídia Cukovskaia, op. cit., p., 123.

8 Vozes abafadas: a poesia atrás da cortina de ferro, Nova Iorque, 1952, publicada pelo emigré Vladimir Markov (estudioso muito conhecido, mesmo na Itália, por uma cuidadosa História do futurismo russo).

Remo Faccani é professor de Literatura Russa na Universidade de Údine.

Tradução de Pedro Garcez Ghirardi. O original em italiano - Riverberi da uno specchio in frantumi: per un canone lirico del novecento russo - encontra-se à disposição do leitor no IEA-USP para eventual consulta. 